\title{
SUSTAINABILITY EFFORTS IN THE HOTEL INDUSTRY: A SYSTEMATIC LITERATURE REVIEW
}

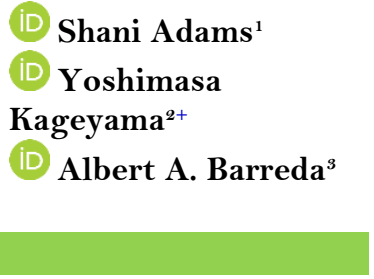

Article History

Received: 13 December 2021 Revised: 17 January 2022 Accepted: 31 January 2022 Published: 11 February 2022

\section{Keywords}

Sustainability

Sustainability challenges

Green practices

Green hotels

Systematic literature review.

\author{
1.,2 Department of Hospitality Leadership, Missouri State University, USA. \\ Email:az54@live.missouristate.eduTel:14178364409 \\ Email:1Kageyama@missouristate.eduTel:+14.178365020 \\ ${ }^{s}$ Email: AlbertBarreda@missouirstate.edu Tel: +14178364223
}

\begin{abstract}
Many definitions have been offered for the term "sustainability" within the hotel industry, and because of this, many business owners have been skeptical of what the term really means, and all that it encompasses; this uncertainty has, unfortunately, rendered them hesitant to initiate any efforts towards accepting it within their hotel doors and within their business plan. The aim of this research is to provide a sense of a road map to sustainability efforts within the Hotel Industry (all around the world); provide an array of options for new innovative sustainability efforts for hoteliers; and a look into what sustainability efforts actually exists in the industry today. The author statistically analyzed a total of 45 articles and journals and narrowed them down to twenty-seven which were most relevant to the research topic. The results show that not only is sustainability in the Hotel Industry very relevant, but that there are also many creative ways (through construction, technology, etc.) in which hoteliers are placing sustainable efforts at the forefront of their business strategies, evidenced in the growth of their customer base and customer satisfaction, reduction of their carbon footprint, as well as an increase in their overall corporate rating amongst hotels globally. The results of the review also identified the gap in the existing literature relating to sustainability in hotels.
\end{abstract}

Contribution/Originality: This study identifies the gap between the dimensions of sustainability in theory and ones being studied in literature. The results found that existing research has focused on the environmental aspect of sustainability while neglecting economic and social aspects of sustainability in hotels.

\section{INTRODUCTION}

Sustainability efforts are extremely important to the environmental, social, and economic development of the world. Though there is no one final definition of what sustainability is, the consensus is that sustainability is "the efforts which are made today which do not hinder the survival of other generations in the future". The more businesses that get onboard with sustainability efforts, the better, not only for the environment, but also for their long-term customer retention and profitability (Grant, 2020). The topic of sustainability is relevant for hotels because the lodging sector is a major contributor to environmental problems consuming natural resources such as water and energy (Verma \& Chandra, 2018). There is a growing concern for the negative impacts of the hotels on the environment (Tooman, Sloan, Legrand, \& Fendt, 2008). Therefore, it is necessary for hotels to adopt environmentally sustainable actions due the size and the rapid growth of the hotel industry (Stipanuk, 2002). Sustainability in the hotel industry is taking on many different avenues; inclusive of technology, construction, 
cultural, environmental, social, and economical (Verma \& Chandra, 2018). Despite of the multifaceted nature of sustainability in hotels, the literature has mainly focused on the environmental perspective associated with the term "green hotels." A green hotel is a hotel which runs an environmentally responsible operation providing guests with sustainable, healthy, and hygienic product and services (Millar \& Baloglu, 2011). Researchers have recognized the complexity of defining green hotels due to the various aspects of sustainability involved (Verma \& Chandra, 2018). With there being so many different definitions of sustainability, it is important that the list be narrowed down to a concrete definition of what this term actually is in order to avoid any further obscurity of the term, and how it can be put into practice. Through reviewing literature, the authors attempt to investigate how sustainability is defined in the hotel industry, when sustainability begins, what are the obstacles and innovations for green practices in hotels. Furthermore, a conceptual qualitative review was conducted to identify the profile of the studies on sustainability in lodging sector and the research topics in existing literature. The analysis of systematic literature review contributes to a holistic understanding of sustainability in hotels literature that existing research has focused on. The finding would identify the aspects neglected and provide directions for future research.

\section{LITERATURE REVIEW}

\subsection{Conceptualization of Sustainability}

The origin of sustainability has been traced back to the 1960's, and according to Sloan, Legrand, and Chen (2017) and Grant (2020) the official definition of sustainability is "the ability to meet the need of the present without compromising the ability of future generations to meet their needs". This was a more concise version to that of Petri and Mikuli (2012) whose definition also added: "it is a global phenomenon which seeks for fair and equitable development for all people within and between generations.” Though Petri and Mikuli (2012) provided us with a definition of sustainability, it was mentioned in her research that there have been over 70 different proposed definitions since the concept first came to life. Petri and Mikuli (2012) went on to mention that her research led to the Brundtland (1987) which allegedly has the most widely cited definition of sustainability: "development is sustainable if the present satisfaction of needs does not question the ability of the future generations to satisfy their needs". Regardless of the source or even the period during which sustainability was defined, the three definitions provided above, generally say the same thing and convey the same message. Sustainability was built on three pillars: social, economic, and environmental. Through these three pillars, businesses are encouraged to consider, and to look towards more long-term factors rather than towards the next quarter's profits/earnings/losses, and by doing this, they are then able to put plans in place to cut emissions, properly dispose of physical waste with as little carbon footprint as possible, and lower energy usage (Grant, 2020). Figure 1 shows a visual of these three dimensions and some considerations to be tackled by hotel businesses that aim to become fully sustainable.

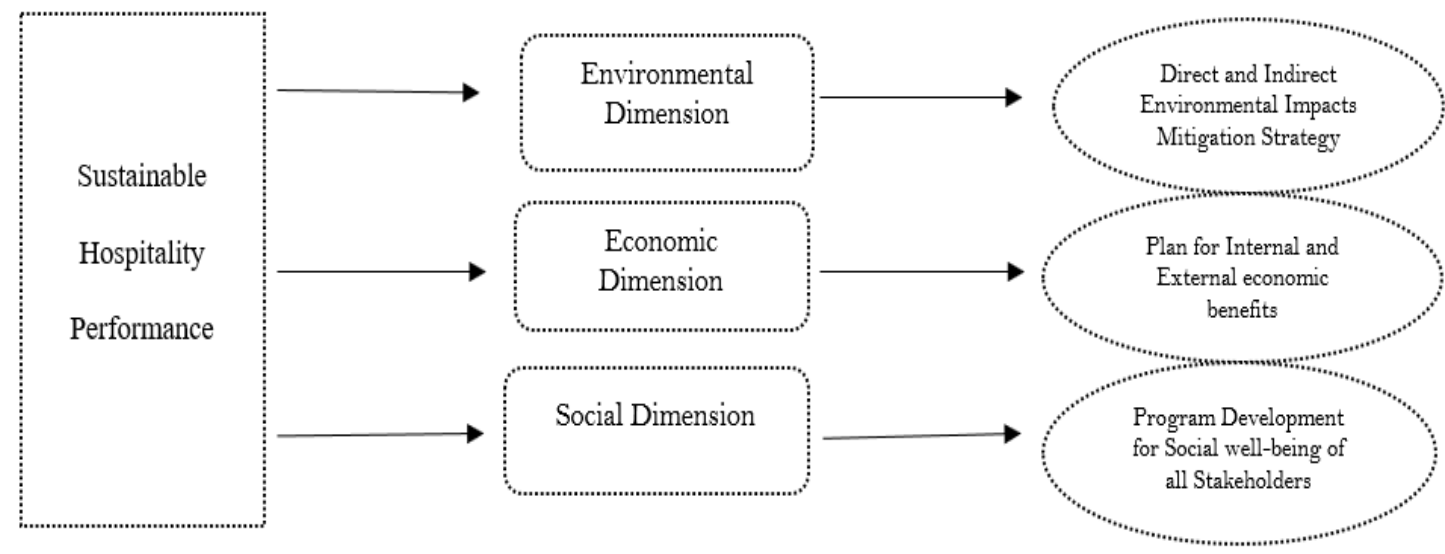

Figure 1. Three dimensions of sustainability. 
Figure 1 model was originally constructed by Sloan et al. (2017). The authors of this research paper rejuvenated and redesigned it to show a forward movement in the progression of sustainability in hotels, instead of a downwards movement as designed by Sloan et al. (2017). The environmental dimension considers "life support system" such as soil which needs to be sustained for economic production or human life to happen. The economic sustainability emphasizes natural resources that provide inputs for economic outputs. On the other hand, the social dimension considers the human aspects include the attempts to eliminate poverty and hunger (Goodland, 1995). The figure provides three dimensions of sustainable hospitality practices and how hospitality businesses can address those three components.

\subsection{Corporate Social Responsibility as Sustainability Initiative}

According to Punitha and Rasdi (2013) there is a lack of agreement on definitions of Corporate Social Responsibility in a pre-paradigmatic phase indicating that there is little to no consensus being reached on what is included or excluded in the boundaries of this term. There has been a total of 37 definitions pertaining to Corporate Social Responsibility (CSR), for which the general consensus is " $[\mathrm{CSR}]$ is the social responsibility of businesses [which] encompasses the economic, legal, ethical, and discretionary expectations that society has of organizations at a given point in time" Punitha and Rasdi (2013). Economic, in that businesses are responsible for providing jobs to the society; providing a return on investment to the shareholders as well as the owners; and producing goods and services for a profit (Walsh \& Dodds, 2017). The legality aspect ensures that businesses operate in a legal form which is aligned with all regulations and rules and set forth by governing entities (Fournier \& Fall, 2017). Ethical expectations cover the businesses moral responsibilities to society, which encompasses their strategies to sustain the environment for the future generations. Finally, discretionary expectations pertain to the welfare of humankind and spreading good will through the engagement and promotion of voluntary programs and humanitarian efforts (Punitha \& Rasdi, 2013).

\subsection{Sustainability in the Hotel Industry}

The environmental aspect of sustainability is seen as viability and healthy ecological systems (Peng, Kellens, Tang, Chen, \& Chen, 2018). Human consumption as it relates to our carbon footprint, whether it be food, construction of buildings, transportation of employees and guests to and from the facility, or water usage plus depletion, all of which come into play before, during, and after the existence of the hotel business (Burton, 2019). The social aspect of sustainability strengthens social capital through empowerment, which in turn reduces vulnerability and maintains the health of cultural and social systems; it basically encompasses the activities of the business, which they use to enhance the daily lives and well-being of either their community or their individual customers (Webster \& Courtnell, 2019). Finally, the economic segment promotes growth in the consumption of services and goods, which in the long run improves human welfare (Petri \& Mikuli, 2012). This refers to the profit mentality of business owners and provides hoteliers with the opportunity to create a win-win situation through the use of efficient sustainable efforts (Kim, Barber, \& Kim, 2019) which would help the environment, as well as provide them with a bigger profit in the long run (Kasemsap, 2018). Both the environmental and the social aspect of sustainability is heavily dependent of the relationship with and attitude of management, owners, operators, and franchisor/franchisees, towards sustainability efforts within the industry, which is mostly due to the involvement of vast structural changes (Aznar, Sayeras, Galiana, \& Rocafort, 2016). Zhang, Joglekar, and Verma (2012) states that hospitality industry leaders in the United States consider sustainability their top concern. The reason is that the industry lacks uniform industry reporting standards. As a result of this inconsistency which leads to false reporting, it was suggested that there be an industry-wide measure for environmental sustainability, which would capture the environmental and the economic initiative efforts of the industry leaders (Petri \& Mikuli, 2012). However, the 
presence of idiosyncratic measures has made it challenging to have a comparison of the findings and a generalization across the studies (Petri \& Mikuli, 2012).

\subsection{Green Hotels and Sustainable Practice}

As records show, the hotel sector has major influence on the environment through energy \& water consumption, as well as through consumable goods, and many promoters of sustainability believe that it is time they all jump on board and make the sacrifice today (Walsh \& Dodds, 2017) so that generations to come would still have a [relatively] clean world to live in Lim (2017). According to BA (Hons) Hotel and Hospitality Management (2020) sustainability is widely regarded as the key to successful businesses (both public and private sector) in the $21^{\text {st }}$ century. According to Nastu (2017) while it true that the hotel industry relies on the natural environment [sandy beaches, untainted landscapes, waterfalls, fresh air, etc.] in order to efficiently serve its guests, it still puts an increased amount of pressure on the environment, and depends heavily on natural resources. As a result, there has been a growing concern among some industry professionals, of their actions causing inherent danger to the very basis that their businesses are built upon (BA (Hons) Hotel and Hospitality Management, 2020). This realization, paired with government pressures and competitors in the general hospitality industry, quickly motivated hoteliers to jump onboard with sustainability efforts and make it a part of their company's corporate agenda (Grant, 2020). This gave birth to the "going green" term that is well known in industry today, which, in turn, then led to the "reduce, reuse, recycle" policies and practices being put into place (Zolfani, Pourhossein, Yazdani, \& Zavadskas, 2018) and some of the major hotel brands publishing their sustainability reports regularly (Guix, Bonilla-Priego, \& Font, 2018).

\subsection{Challenges to the Growth of Sustainability in the Hotel Industry}

Sustainability within the lodging/corporate sector was established as a result of customer dissatisfaction towards the long-term damage on the environment which was found to be caused by the short-term profit mentality of businesses in the industry (Al-Wattar, Almagtome, \& AL-Shafeay, 2019). Businesses found it hard to commit to the sustainability efforts because of the high-cost and slow-returns that they were expected to see after implementing sustainable practices (Grant, 2020). However, it was found that in general, the running cost for hotels who are considered sustainable, is much lower than hotels who haven't put any sustainable plans in place within their businesses (Nastu, 2017). Hoteliers who are willing to make a great investment into these efforts for the good of the environment, the good of society and the future generations to come, usually reap quite positive financial rewards, high customer ratings, and high comparative ratings amongst their peers (Walsh \& Dodds, 2017). Despite these benefits, hoteliers are still hesitant about taking the plunge when it comes to incorporating sustainable efforts into their business. According to Zhang, Wu, Liu, and Zhang (2017) despite financial benefits from reducing water and energy usage, as well as water cost, hoteliers still worry that their financial performance (if they become a green hotel) may erode if recycling, resource savings, or green activities result in their customers being uncomfortable or inconvenienced in any way, especially seeing that customers pay such close attention to such aspects when they travel (Han, Hsu, \& Lee, 2009).

However, this is where the use of studies and surveys come into play, especially knowing that customers do not directly benefit from the hotel's energy saving efforts. According to a study which was based in China (due to there being several unique datasets in Beijing - which is ideal for research), residents are willing to pay higher prices for a hotel that is considered "green" when their living comfort is improved. The study concluded that the rate of guest complaints pertaining to environmental comfort was 19\% lower than those of the non-green hotels, and that guests were willing to pay a $6.5 \%$ premium for said green hotels as long as the living comfort improved (Han et al., 2009; Zhang et al., 2017). 


\subsection{Sustainable Innovation in Hotel Industry}

Guests in the hotel industry are increasingly demanding sustainable hospitality during their stay; from sustainable practices, to sustainable architecture, and sustainable construction; this demand is projected to be dominated by the vast developments in the technology industry (Eskerod, Hollensen, Morales-Contreras, \& Arteaga-Ortiz, 2019). A project proposed by Canadian Firm, Arno Matis Architecture called Vertical MicroClimate Hotel, which basically allows hotels in North America to be habitable year-round (Nastu, 2017). This project used heliostat technology, which is a mirroring system used to reflect the sun back into specific areas of the hotel, which warms the area up, therefore making it habitable even in colder conditions. Another trend which could be used to help hotels reduce their carbon footprint is the concept of the suspension of hotels from the tops of trees with the use of a cable system above a trampoline-like platform (Nastu, 2017). The Taiwan hotel industry is also jumping on board in the form of culturally-sustainability efforts, with the utilization of the Play Design Hotel (Nastu, 2017). This design is said to "champion local artists and designers by installing their creations into hotel rooms and encouraging guests to interact with them" (Nastu, 2017).

\section{METHODOLOGY}

\subsection{Systematic Model of the Research}

The research was done via a systematic quantitative review process, through the analysis of 45 articles in various formats (journals, university thesis, research books, and online websites), with the aim of collecting data on sustainable efforts in the hotel industry, and it was designed to give an overview of the topic and identify the gap in this topic. The research was modeled based on a model designed by Yang, Khoo-Lattimore, and Arcodia (2017) which shows the entire research process (Start: defining the goal of the research, to finish: finalizing the research findings) as can be seen in Figure 2. Systematic quantitative review process involves a systematic process of searching literature, extracting relevant articles, and synthesizing the selected literature (Pickering, Grignon, Steven, Guitart, \& Byrne, 2015).

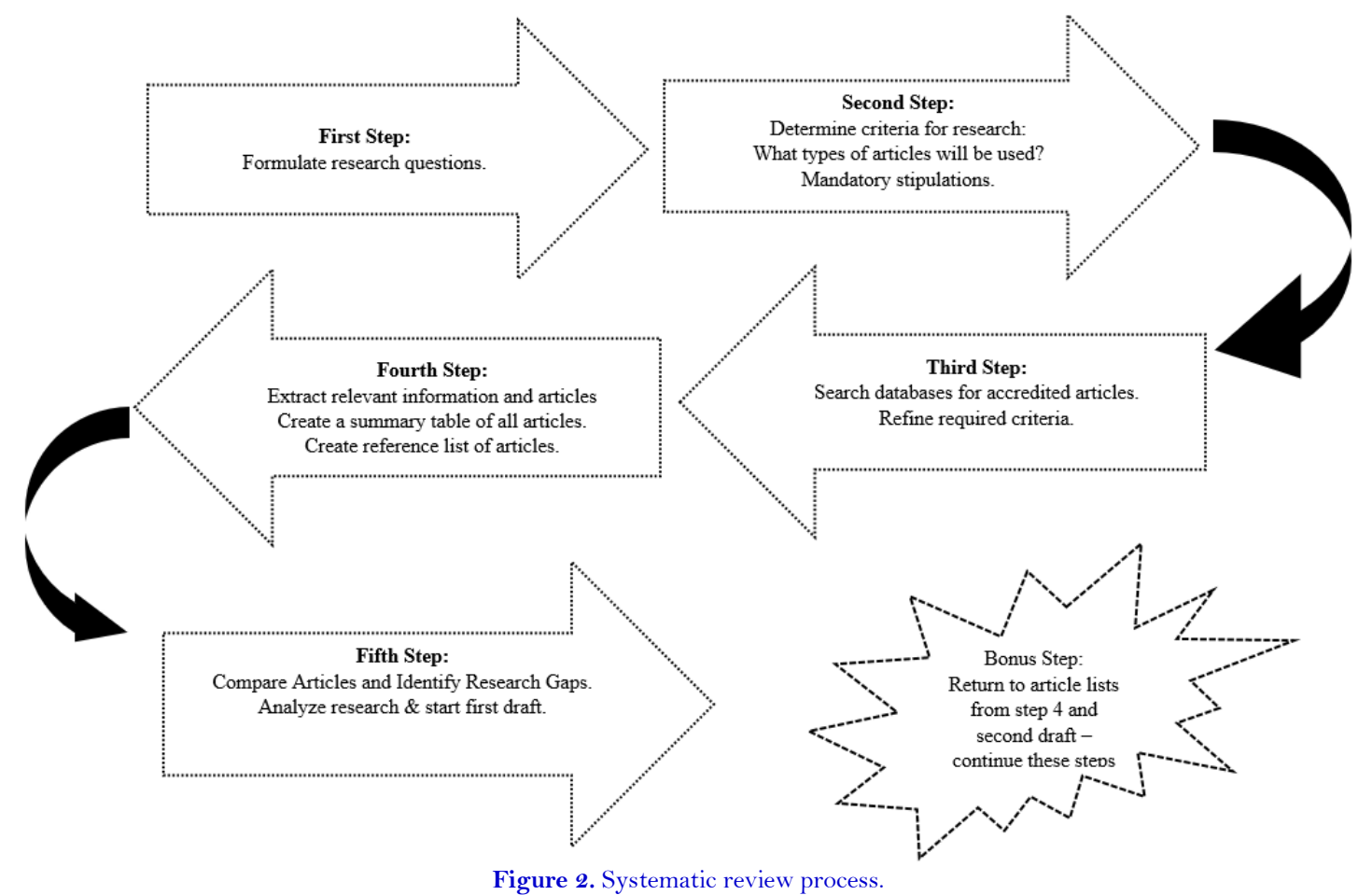

Figure 2. Systematic review process 
The authors started the research project by devising a plan to complete the research, which started as a result of the author's curiosity \& interest in the topic. The first step was to formulate the questions that the authors wanted to answer in research, which resulted in: what are the profiles of existing literature on sustainability in hotels and what are the topics being included in existing literature. Step 2 was determining the criteria that was going to be used to determine the usefulness of the articles that would be reviewed, which varied, to gain a wide array of opinions, and points of view on the topic. The main stipulation that was held throughout all references was that the articles could be no older than 10 years old. The third step was to search on google scholar for all articles relating to 'sustainability in hotels', which resulted in 146,000 articles. The authors then applied filters such as "English", and timeline of "2009-2019", which then led to 47,800 results. At this point, the authors decided to consider articles which included "sustainability in hotels" within the title, in order to achieve a narrower scope of information, which yielded 91 results. This then led into Step 4, where the authors scaled over about half of the 91 articles and ended up choosing 20 of those articles to review, which is when the authors circled back to the 47,800 results from step 3, to see what other types of 'sustainability' research was available, in order to give research a more well-rounded approach / feel to it. From this search, the authors then extracted another 25 articles which included topics on sustainable buildings, sustainable technology, sustainable behavior, etc. (as mentioned above). With step 5, the authors began the content analysis, and started the first drafting of the research paper. For the final step obtained 25 articles. The authors decided to add a bonus step, which was a combination of steps $4 \& 5$ until the final draft is achieved. Step 3 and 4 (\&bonus step) are shown in a visual below in Figure 3.

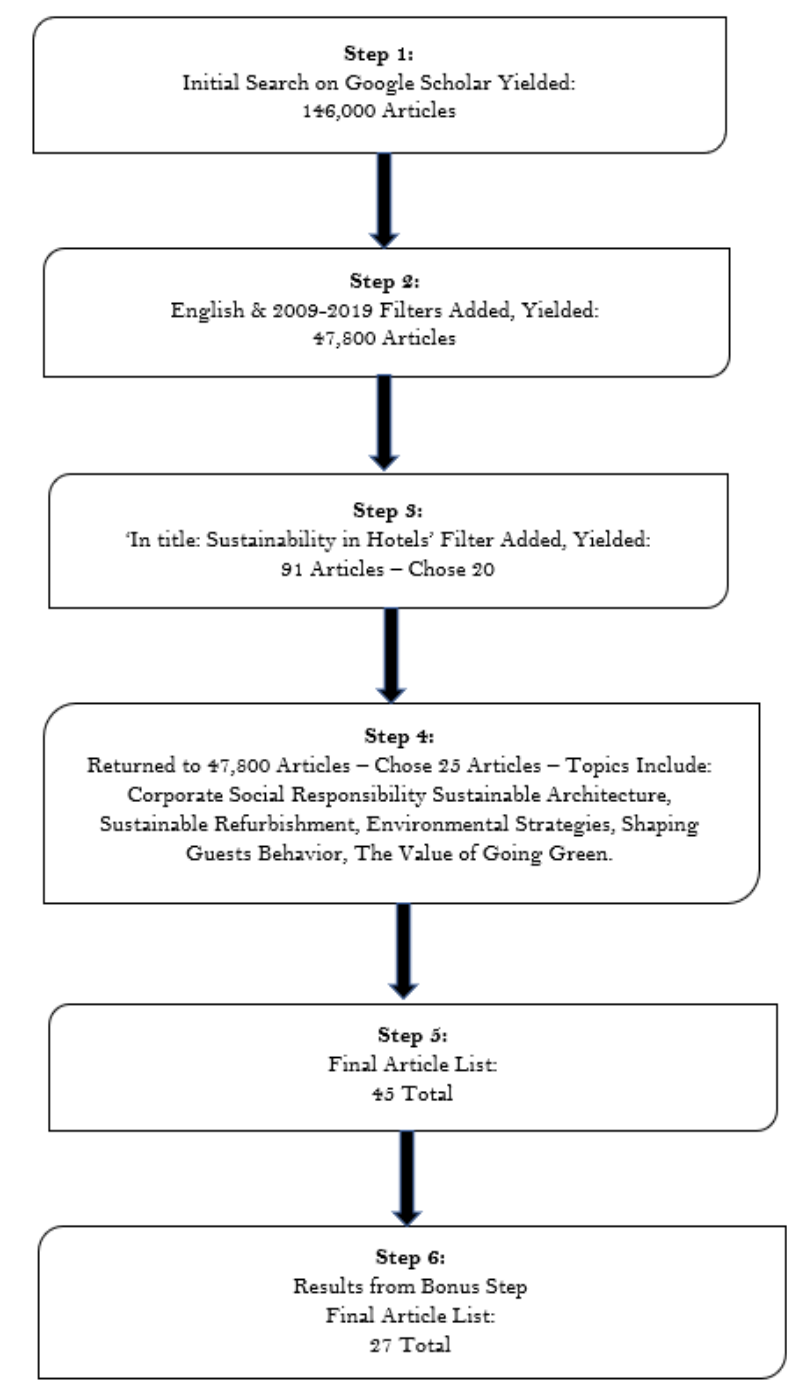

Figure 3. Visual of steps $3 \& 4$ of selection process (\& Bonus Step). 
Table 1. Literature profiles \& publication years.

\begin{tabular}{l|c|c|c}
\hline Type & No. of Studies & Year & Study Location \\
\hline $\begin{array}{l}\text { Turkish Online Journal of Design, Art } \\
\text { and Communication }\end{array}$ & 1 & 2016 & Bandar Abbas: Iran \\
\hline Online database & 8 & $2011-2020$ & $\begin{array}{c}\text { Hungary, Tehran: Iran, USA, } \\
\text { United Kingdom, Croatia. }\end{array}$ \\
\hline Cornell Hospitality Quarterly & 2 & $2012 \& 2013$ & USA \\
\hline Books & 2 & $2016 \& 2019$ & England \& USA \\
\hline Tourism Management Journal & 3 & $2015-2017$ & Spain \& Thailand \\
\hline Emerald Insight Journal & 1 & 2012 & USA \\
\hline Blog Journal of Hospitality & 1 & 2017 & USA \\
\hline $\begin{array}{l}\text { International Jungary } \\
\text { Management }\end{array}$ & 2 & 2009 & Malaysia \& USA \\
\hline Journal of Sustainable Development & 1 & 2017 & London \\
\hline Journal of Business and research & 1 & 2013 & Mumbai: India \\
\hline $\begin{array}{l}\text { Asian Social Science - Canadian Center of } \\
\text { Science and Education }\end{array}$ & 1 & 2019 & Beijing \\
\hline Routledge & 2 & $2009 \& 2016$ & \\
\hline $\begin{array}{l}\text { International Journal of Environmental } \\
\text { Technology and Management }\end{array}$ & 1 & 2017 & \\
\hline Real Estate Economics & & & \\
\hline
\end{tabular}

\section{FINDINGS}

\subsection{Literature Profiles \& Publication Years}

Listed in Table 1 are the publication types, year published, number of articles published by each, and the location that each article was based in for the publications which were found to be most relevant to the sustainability research at hand. A variety of research bases were used in the effort to provide a wide array of opinions and practices in sustainability around the world, to promote authenticity in the research and to provide hoteliers \& readers of this research with a well-rounded knowledge base on such efforts. This data is listed out in more detail in the following sections.

\subsection{Research Topics \&ं Percentages}

It was found that of the articles reviewed, $28 \%$ of them focused on sustainable marketing \& drivers of sustainability in hotels, $16 \%$ focused on sustainable architecture \& construction in hospitality, $12 \%$ focused on the importance of sustainability in hotel management, $12 \%$ focused on eco-friendly decision-making process, $7 \%$ focused on shaping guests' sustainable behavior through mindfulness, $7 \%$ focused on sustainable technology, $6 \%$ focused on corporate social responsibility, $5 \%$ focused on sustainability in hotels around the world, $4 \%$ focused on the future of sustainability in hospitality, and the last $3 \%$ focused on learning and innovation in sustainability, as can be shown in Table 2. Table 3 presents the summary of the articles for the systematic review.

Table 2. Research topics \& percentages.

\begin{tabular}{l|c}
\hline Topics of Research & Percentage of Articles \\
\hline Sustainable Marketing \& Drivers of Sustainability in Hotels & $28 \%$ \\
\hline Sustainable Architecture \& Construction on Hospitality & $16 \%$ \\
\hline The Importance of Sustainability in Hotel Management & $12 \%$ \\
\hline Eco-Friendly Decision-Making Process & $12 \%$ \\
\hline Shaping Guests' Sustainable Behavior Through Mindfulness & $7 \%$ \\
\hline Sustainable Technology & $7 \%$ \\
\hline Corporate Social Responsibility & $6 \%$ \\
\hline Sustainability in Hotels Around the World & $5 \%$ \\
\hline The Future of Sustainability in Hospitality & $4 \%$ \\
\hline Learning \& Innovation in Sustainability & $3 \%$ \\
\hline
\end{tabular}


Table 3. Article summary results.

\begin{tabular}{|c|c|c|c|c|}
\hline Author Name & Academic title \& source & Year & $\begin{array}{l}\text { Research } \\
\text { Type }\end{array}$ & $\begin{array}{l}\text { Research } \\
\text { Design }\end{array}$ \\
\hline $\begin{array}{l}\text { Alidadi and Zadeh } \\
(2016)\end{array}$ & $\begin{array}{l}\text { Designing A Five Star Hotel with The Approach } \\
\text { of Sustainable Architecture in Bandar } \\
\text { Abbas. Turkish Online Journal of Design, Art } \\
\text { and Communication. }\end{array}$ & 2016 & $\begin{array}{l}\text { Qualitative } \\
\text { \& Quantitative }\end{array}$ & Other \\
\hline $\begin{array}{l}\text { BA (Hons) Hotel } \\
\text { and Hospitality } \\
\text { Management } \\
(2020)\end{array}$ & BA (Hons) Hotel and Hospitality Management & 2020 & Qualitative & Other \\
\hline $\begin{array}{l}\text { Barber and Deale } \\
(2013)\end{array}$ & $\begin{array}{l}\text { Tapping Mindfulness to Shape Hotel Guests' } \\
\text { Sustainable Behavior. Cornell Hospitality } \\
\text { Quarterly. }\end{array}$ & 2013 & Quantitative & Survey \\
\hline Burton (2019) & $\begin{array}{l}\text { Handbook Of Sustainable Refurbishment: } \\
\text { housing. S.l.: Routledge. }\end{array}$ & 2019 & Quantitative & Case Study \\
\hline $\begin{array}{l}\text { Eskerod et al. } \\
(2019)\end{array}$ & $\begin{array}{l}\text { Drivers for Pursuing Sustainability through IoT } \\
\text { Technology within High-End Hotels-An } \\
\text { Exploratory Study. Sustainability. }\end{array}$ & 2019 & Qualitative & Case Study \\
\hline $\begin{array}{l}\text { Fraj, Matute, and } \\
\text { Melero (2015) }\end{array}$ & $\begin{array}{l}\text { Environmental strategies and organizational } \\
\text { competitiveness in the hotel industry: The role } \\
\text { of learning and innovation as determinants of } \\
\text { environmental success. Tourism Management. }\end{array}$ & 2015 & Quantitative & Case Study \\
\hline Grant (2020) & $\begin{array}{l}\text { Understanding Sustainability. Available At: } \\
\text { https://www.investopedia.com/terms/s/sustain } \\
\text { ability.asp }\end{array}$ & 2020 & Qualitative & $\mathrm{N} / \mathrm{A}$ \\
\hline $\begin{array}{l}\text { Gohardani and } \\
\text { Björk (2012) }\end{array}$ & $\begin{array}{l}\text { Sustainable refurbishment in building } \\
\text { technology", Smart and Sustainable Built } \\
\text { Environment. }\end{array}$ & 2012 & Qualitative & Other \\
\hline Harmon (2017) & $\begin{array}{l}\text { The Future of Sustainability in the Hospitality } \\
\text { Industry. Available At: } \\
\text { https://www.bluecart.com/blog/the-future-of- } \\
\text { sustainability-in-the-hospitality-industry. }\end{array}$ & 2017 & Qualitative & Other \\
\hline Han et al. (2009) & $\begin{array}{l}\text { Empirical Investigation of the Roles of Attitudes } \\
\text { toward Green Behaviors, Overall Image, } \\
\text { Gender, and Age in Hotel Customers' } \\
\text { Eco-Friendly Decision-Making } \\
\text { Process. International Journal of Hospitality } \\
\text { Management }\end{array}$ & 2009 & $\begin{array}{l}\text { Qualitative } \\
\text { \&Quantitative }\end{array}$ & Other \\
\hline Kasemsap (2018) & $\begin{array}{l}\text { Encouraging Corporate Social Responsibility } \\
\text { and Sustainable Tourism Development in Global } \\
\text { Tourism. Corporate Social Responsibility in the } \\
\text { Hospitality and Tourism Industry Advances in } \\
\text { Hospitality, Tourism, and the Services Industry. }\end{array}$ & 2018 & Quantitative & Survey \\
\hline Lengyel (2015) & $\begin{array}{l}\text { Mindfulness and Sustainability: Utilizing the } \\
\text { Tourism Context. Journal of Sustainable } \\
\text { Development. }\end{array}$ & 2015 & Quantitative & Other \\
\hline $\operatorname{Lim}(2017)$ & $\begin{array}{l}\text { Inside the sustainable consumption theoretical } \\
\text { toolbox: Critical concepts for sustainability, } \\
\text { consumption, and marketing. Journal of Business } \\
\text { Research. }\end{array}$ & 2017 & Qualitative & Case Study \\
\hline Nastu (2017) & $\begin{array}{l}\text { Sustainability In the Hotel Industry Driven by } \\
\text { Demand. Available At: } \\
\text { https://www.environmentalleader.com/2017/10 } \\
\text { / 174680/ }\end{array}$ & 2017 & $\mathrm{~N} / \mathrm{A}$ & Other \\
\hline $\begin{array}{l}\text { Petri and Mikuli } \\
(2012)\end{array}$ & $\begin{array}{l}\text { Protected areas and tourism development on } \\
\text { Croatian islands: coexistence or divergence? }\end{array}$ & 2012 & Quantitative & $\begin{array}{c}\text { Conceptual } \\
\text { Review }\end{array}$ \\
\hline $\begin{array}{l}\text { Punitha and Rasdi } \\
\text { (2013) }\end{array}$ & $\begin{array}{l}\text { Corporate Social Responsibility: Adoption of } \\
\text { Green Marketing by Hotel Industry. Asian } \\
\text { Social Science. }\end{array}$ & 2013 & Quantitative & Case Study \\
\hline
\end{tabular}




\begin{tabular}{|c|c|c|c|c|}
\hline Author Name & Academic title \& source & Year & $\begin{array}{l}\text { Research } \\
\text { Type }\end{array}$ & $\begin{array}{l}\text { Research } \\
\text { Design }\end{array}$ \\
\hline $\begin{array}{l}\text { Rahman, Reynolds, } \\
\text { and Svaren (2012) }\end{array}$ & $\begin{array}{l}\text { How "green" are North American hotels? An } \\
\text { exploration of low-cost adoption practices. } \\
\text { Available At: } \\
\text { https://www.sciencedirect.com/science/article/ } \\
\text { abs/pii/So278431911001526. }\end{array}$ & 2011 & Quantitative & Case Study \\
\hline $\begin{array}{l}\text { Rosa and Silva } \\
(2017)\end{array}$ & $\begin{array}{l}\text { Environmental sustainability in hotels, } \\
\text { theoretical and methodological contribution. } \\
\text { Available at ://www.scielo.br/ } \\
\text { scielo.php? script=sci_arttext\&pid=S1982- } \\
61252017000100039 \& \ln g=\text { en\&nrm=iso\&nrm=i } \\
\text { so\&tlng=en }\end{array}$ & 2020 & Quantitative & Other \\
\hline Ryu (2014) & $\begin{array}{l}\text { Sustainable Building Refurbishment. Master's } \\
\text { Thesis: Aalto University, Espoo, Finland. }\end{array}$ & 2014 & Qualitative & Case Study \\
\hline Sloan et al. (2017) & $\begin{array}{l}\text { Sustainability in the hospitality industry } \\
\text { principles of sustainable operations (3rd ed.). } \\
\text { London: Routledge. }\end{array}$ & 2017 & Quantitative & Case Study \\
\hline Tanveer (2019) & $\begin{array}{l}\text { Top 7: World's Most Sustainable Hotels. } \\
\text { Available At: } \\
\text { https://www.abouttimemagazine.co.uk/travel/t } \\
\text { op-7-worlds-most-sustainable-hotels/ }\end{array}$ & 2019 & Qualitative & Other \\
\hline $\begin{array}{l}\text { Tripathi and Singh } \\
(2016)\end{array}$ & $\begin{array}{l}\text { Determinants of sustainable/green consumption: } \\
\text { a review. International Journal of Environmental } \\
\text { Technology and Management. }\end{array}$ & 2016 & Quantitative & Other \\
\hline $\begin{array}{l}\text { Webster and } \\
\text { Courtnell (2019) }\end{array}$ & $\begin{array}{l}\text { Economic Sustainability for Success: What It Is } \\
\text { and How to Implement It: Process Street: } \\
\text { Checklist, Workflow and SOP Software. } \\
\text { Available At: https://www.process.st/economic- } \\
\text { sustainability/ }\end{array}$ & 2019 & Qualitative & Other \\
\hline Yang et al. (2017) & $\begin{array}{l}\text { A systematic literature review of risk and gender } \\
\text { research in tourism. Tourism Management. }\end{array}$ & 2017 & Quantitative & Case Study \\
\hline Zhang et al. (2012) & $\begin{array}{l}\text { Exploring Resource Efficiency Benchmarks for } \\
\text { Environmental Sustainability in Hotels. Cornell } \\
\text { Hospitality Quarterly. }\end{array}$ & 2012 & Quantitative & Other \\
\hline Zhang. et al. (2017) & $\begin{array}{l}\text { The Value of Going Green in the Hotel } \\
\text { Industry: Evidence from Beijing. Real Estate } \\
\text { Economics. }\end{array}$ & 2017 & Qualitative & $\begin{array}{l}\text { Conceptual } \\
\text { Review }\end{array}$ \\
\hline Zolfani et al. (2018) & $\begin{array}{l}\text { Evaluating construction projects of hotels based } \\
\text { on environmental sustainability with MCDM } \\
\text { framework. Available At: } \\
\text { https://www.sciencedirect.com/science/article/ } \\
\text { pii/S1110016816303003 }\end{array}$ & 2017 & Qualitative & Case Study \\
\hline
\end{tabular}

\subsection{Article Summary Results}

Table 4, also displays below, displays sample type, statistical analysis, first author's location, and study location. Table 5 displays that both the research type and research design can be seen showing frequency and percentages. The sample type yielded results from everything from hotels, to hospitality industry, to hospitality buildings, to Spanish hotels, to single \& multi-family dwellings, to hotel guests, to academia articles, to trends on google, etc.

The statistical analysis results indicated that exploratory analysis reviews was the most utilized analysis method followed by content analysis reviews and empirical analysis reviews. The rest of the analysis methods used were: analytical-descriptive analysis reviews, prescriptive analysis reviews, partial squares analysis reviews, inferential analysis reviews, mechanistic analysis reviews, structural equation analysis review, systematic analysis reviews, hedonic analysis reviews, and descriptive analysis reviews. A vast majority of articles were based in the USA, followed by $7.4 \%$ based in the UK and $7.4 \%$ based worldwide. The rest of the locations were: Iran, Spain, Hungary, Thailand, Taiwan, Croatia, and China. 
Similarly, Table 5 contains research type/design and its respective frequency and percentage. The research type resulted in $48 \%$ of the articles being quantitative, $41 \%$ of the articles being qualitative, $7 \%$ of the articles being both qualitative \& quantitative, and the last $4 \%$ of the articles being research letter or a similar type. The research design yielded a variety of different results: $44.4 \%$ of the articles being other (e.g. mixed) research design, $37 \%$ of the articles being in case study design, $15 \%$ of the articles being survey design, and $4 \%$ of the articles being conceptual design.

Table 4. Statistical analysis and location

\begin{tabular}{|c|c|c|c|}
\hline Sample Type & Statistical analysis & Study location & First author location \\
\hline Library Resources, Photographs. & Analytical-Descriptive & Bandar Abbas: Iran & Bandar Abbas: Iran \\
\hline Unknown & Casual Analysis & UK & UK \\
\hline Hotel Guest & Exploratory Analysis & USA & USA \\
\hline Single \& Multi-family Dwellings & Exploratory Analysis & UK & UK \\
\hline High-End Hotels & $\begin{array}{l}\text { Exploratory \& } \\
\text { Prescriptive Analysis }\end{array}$ & USA & USA \\
\hline Spanish Hotels & Partial Least Squares & Spain & Spain \\
\hline $\mathrm{N} / \mathrm{A}$ & Inferential Analysis & USA & USA \\
\hline Hospitality Buildings & Mechanistic Analysis & USA & USA \\
\hline General Hospitality Industry & Casual Analysis & USA & USA \\
\hline Men \& Women & $\begin{array}{l}\text { Structural Equation } \\
\text { Analysis }\end{array}$ & USA & USA \\
\hline Hospitality \& Tourism Literature & Exploratory Analysis & USA & USA \\
\hline $\begin{array}{l}\text { Google Trends on Travelers in the } \\
\text { Hospitality and Tourism Industry }\end{array}$ & Empirical Analysis & Hungary & Hungary \\
\hline Marketing Research & Exploratory Analysis & USA & Thailand \\
\hline $\begin{array}{l}\text { Sustainable Hospitality Trends Via } \\
\text { Google Hotels }\end{array}$ & $\begin{array}{l}\text { Causal Analysis } \\
\text { Empirical Analysis }\end{array}$ & $\begin{array}{l}\text { Taiwan } \\
\text { Croatia }\end{array}$ & $\begin{array}{l}\text { Taiwan } \\
\text { Croatia }\end{array}$ \\
\hline University Databases & Content Analysis & Malaysia & Malaysia \\
\hline AHLA Properties & Exploratory Analysis & USA & USA \\
\hline Academia Articles & $\begin{array}{ll}\text { Exploratory } & \& \\
\text { Descriptive Analysis } & \end{array}$ & USA & Brazil \\
\hline Papers, Interviews, and Databases. & Content Analysis & USA & Finland \\
\hline Academia Databases & Content Analysis & USA & Germany \\
\hline Hotels & Content Analysis & Worldwide & USA \\
\hline Research Papers & Content Analysis & Worldwide & Mumbai: India \\
\hline Unknown & Exploratory Analysis & USA & USA \\
\hline Tourism Risk Literature & Systematic Analysis & Thailand & Thailand \\
\hline Financial Data & $\begin{array}{l}\text { Exploratory Factor } \\
\text { Analysis }\end{array}$ & USA & USA \\
\hline Online Reviews & $\begin{array}{l}\text { Hedonic Regression } \\
\text { Analysis }\end{array}$ & China & USA \\
\hline
\end{tabular}

Table 5. Research type \& design statistics.

\begin{tabular}{l|c|c}
\hline Type/ Design (total:27) & Research type frequency (n) & Percentage (\%) \\
\hline Quantitative & 13 & 48 \\
\hline Qualitative & 11 & 41 \\
\hline Mixed & 2 & 7 \\
\hline N/A & 1 & 4 \\
\hline Research Design (total:27) & 10 & 37 \\
\hline Case Study & 12 & 44 \\
\hline Other (e.g. Mixed Design) & 4 & 15 \\
\hline Survey & 1 & 4 \\
\hline Conceptual Design & 27 & 100 \\
\hline Total & &
\end{tabular}




\section{DISCUSSIONS AND CONCLUSIONS}

Sustainability is "the ability to meet the need of the present without compromising the ability of future generations to meet their needs" (Grant, 2020). Globally, it is a phenomenon related to the search for equitable and fair and development for all populations within and between generations. Sustainability in hotels seems to be a topic that has peeked a lot of interest around the world. From 2009-2019 there were at least 91 published articles with 'sustainability in hotels' in the title. A conceptual qualitative review was conducted to identify the profiles of the existing literature and the topics related to sustainability in hotels. A variety of research bases were used in the effort to provide a wide array of opinions and practices in sustainability around the world, to promote authenticity in the research and to provide hoteliers \& readers of this research with a well-rounded knowledge base on such efforts. The results of the study were a bit one-sided in terms of the location of the studies. With a vast majority being based in the US, there wasn't enough data to make it an equal comparison and the rest of the world, to see what some differences in sustainability measures that were implemented. The research type of the studies was almost half and half in terms of qualitative and quantitative data, which provided a good variant of data.

As suggested by Petri and Mikuli (2012) there should be an industry-wide environmental sustainability measure, which would capture the environmental and the economic initiative efforts of the industry leaders. The authors believe those topics are needed now more than ever, due to the devastation of the pandemic, which has placed industry professionals in difficult situations and they have had to adapt to this 'new normal' way of living and running businesses. It is time that businesses be held accountable for the impact that they are having on the world, and according to Punitha and Rasdi (2013) this new CSR (Corporate Social Responsibility) trend paired with their realization that their actions are causing inherent danger to the very basis that their businesses are built upon (BA (Hons) Hotel and Hospitality Management, 2020) as well as government pressures and competitors in the general hospitality industry already going green, might be the one thing to hold them accountable and to get them interested in making a change. Utilizing the resources provided, such as the Hotel Carbon Measurement Initiative, Environmental Management for Hotels manual, Design and Construction Manual, and the Hotel Water Management Initiative, are great first steps for hoteliers, businesses in general to make towards becoming green.

Based on the results of the systematic literature review, the most popular topics related to sustainability in hotels is Sustainable Marketing \& Drivers of Sustainability in Hotels. On the other hand, businesses also finds it challenging to commit to sustainability efforts because of the high-cost and slow-returns that they were expected to see after implementing sustainable practices (Grant, 2020). In addition, green activities might result in customers being uncomfortable or inconvenienced in any way (Han et al., 2009). Therefore, it is equally important to investigate the challenges the hoteliers can face considering their willingness to make sustainability efforts and what can be the motivators for those hotel owners who are hesitant to adopt sustainable practices.

According to Harmon (2017) there is little to no doubt that sustainability has taken center-stage in the hospitality industry within the last decade; whether it be commercial goods, meats, commodities, or produce. Sustainability has become the main point of attraction in conversations of both societal and political stature. Harmon states that "[although] there is an undeniably long road ahead of us, the first step in achieving progressive results in sustainability efforts, is [hoteliers and guests] exhibiting a positive shift in attitudes in favor of sustainability".

Based on the literature, sustainability was built on three pillars: social, economic, and environmental (Grant, 2020). Environmentally, the hotel industry needs to maintain viable and healthy ecological systems (Peng et al., 2018) through the consideration of carbon footprint of food, construction of buildings, transportation of employees and guests to and from the facility, or water usage plus depletion (Burton, 2019). Socially the hotel industry needs to reduce vulnerability and maintain the health of cultural and social systems considering the activities of the business implemented to enhance the daily lives and well-being of either their community or their individual customers (Webster \& Courtnell, 2019). Economically, the hotel industry needs to keep the profit mentality of 
business owners and provides hoteliers with the opportunity to create a win-win situation through the use of efficient sustainable efforts (Kim et al., 2019). From the systematic review, the authors recognized that the literature has focused mainly on the environmental aspect of sustainability resulting in a gap in the economic and social aspects of sustainability in hotels.

Technologically based \& culturally based sustainable efforts are projected to take off soon in the hotel industry, and the findings suggest that it would be wise for hoteliers and educators to become as tech savvy as they possible can. It is imperative to the research/progression history, that there be articles which map out the milestones of sustainability in the hotel industry. Finally, the authors will end with this quote by Terry Pratchett (British novelists) - "If you do not know where you come from, then you don't know where you are, and if you don't know where you are, then you don't know where you're going. And if you don't know where you're going, you're probably going wrong."

\section{IMPLICATIONS OF THE STUDY}

The aim of this study was to review sustainable practices in the hotel industry by reviewing a plethora of variants of articles, via google scholar. This paper can be used as a basic overview of sustainability efforts, innovations, ideas, technologies, building designs, and customer behaviors in the Hotel Industry between 20092019, from around the world and not only in the U.S. By touching on different cultures which are getting involved in implementing sustainability efforts in the hotel industry, this research paper serves as a good source for hotels / businesses / or even students who want to get some inspiration of new projects that they too could potentially implement in their own hotels. It was found that some hoteliers find it hard to implement sustainable practices within their business, however, this paper provided statistics that show not only they would be better off implementing these practices, but also that customers would be willing to pay more for such businesses. It was also found that some hoteliers are not aware of the resources that are available to them to help them with this big step into becoming sustainable. This paper provides them with good resources that would be very beneficial with some ideas, locations, and sources that they could use to find out more about sustainability efforts that are already happening around the world. This research paper would also benefit hospitality students as they are learning about sustainability practices in their studies. Majority of professors ask students to keep their research timeline between 5-10 years prior, so this study would provide them with a summary review of the last 10 years of sustainability topics.

\section{LIMITATIONS AND FUTURE RESEARCH}

Sustainability in the future of hotels, the concept of three-dimensional sustainability, the living comfort of green hotels, and the commitment level of hoteliers to the conservation of the environment, would prove to be very intriguing and relevant focuses for research, particularly as they would prove to be beneficial for the sustainable future of the hotel industry. To-date, little or rather lackluster focus has been placed on these areas and it appears that it is the minority who have shown keen interest. Whilst interest in this topic is slowly gaining momentum, current and future generations approach it with more fervor. As it stands, presently, there was a limited pool of available articles for the author to pull from. Although the searches yielded quite a few articles, only a few were available, and the ones that were requested were not approved. Future studies should extend the scope to earlier than 2009, in order to have a more comprehensive and accurate pool of information to choose from. Also, the mindfulness of guests, \& their support of hotels' sustainability efforts should also be explored in-depth, as it is at the core of the success of sustainability efforts in hotel businesses.

Currently, the world is being severely devastated by the effects of the COVID-19 virus, and particularly the hospitality industry, with employees being sent home, and some businesses being forced to shut down. Last suggestions for future research would be to take a look at how the hospitality industry, but more specifically, how 
the hotel industry will bounce back from this, and a look into the new and innovative sustainable ways that some industry professionals have put in place to either keep themselves afloat during this unprecedented time, or what sustainable ideas, industries around the world have created during this disaster. Also, it is believed that it is imperative to the research/progression history, that there be articles which map out the milestones of sustainability in the hotel industry.

Sustainability within the lodging/corporate sector was established as a result of customer dissatisfaction towards the long-term damage on the environment which was found to be caused by the short-term profit mentality of businesses in the industry (Al-Wattar et al., 2019). Businesses found it hard to commit to the sustainability efforts because of the high-cost and slow-returns that they were expected to see after implementing sustainable practices (Grant, 2020). However, it was found that in general, the running cost for hotels who are considered sustainable, is much lower than hotels who haven't put any sustainable plans in place within their businesses (Nastu, 2017). Hoteliers who are willing to make a great investment into these efforts for the good of the environment, the good of society and the future generations to come, usually reap quite positive financial rewards, high customer ratings, and high comparative ratings amongst their peers (Walsh \& Dodds, 2017). Despite these benefits, hoteliers are still hesitant about taking the plunge when it comes to incorporating sustainable efforts into their business. According to Zhang et al. (2017) despite financial benefits from reducing water and energy usage, as well as water cost, hoteliers still worry that their financial performance (if they become a green hotel) may erode if recycling, resource savings, or green activities result in their customers being uncomfortable or inconvenienced in any way, especially seeing that customers pay such close attention to such aspects when they travel (Han et al., 2009). However, this is where the use of studies and surveys come into play, especially knowing that customers do not directly benefit from the hotel's energy saving efforts. According to a study which was based in China (due to there being several unique datasets in Beijing - which is ideal for research), residents are willing to pay higher prices for a hotel that is considered "green" when their living comfort is improved. The study concluded that the rate of guest complaints pertaining to environmental comfort was $19 \%$ lower than those of the non-green hotels, and that guests were willing to pay a $6.5 \%$ premium for said green hotels as long as the living comfort improved (Han et al., 2009; Zhang et al., 2017).

Funding: This study received no specific financial support.

Competing Interests: The authors declare that they have no competing interests.

Authors' Contributions: All authors contributed equally to the conception and design of the study.

\section{REFERENCES}

Al-Wattar, Y. M. A., Almagtome, A. H., \& AL-Shafeay, K. M. (2019). The role of integrating hotel sustainability reporting practices into an accounting information system to enhance hotel financial performance: Evidence from Iraq. African Journal of Hospitality, Tourism and Leisure, 8(5), 1-16.

Alidadi, S., \& Zadeh, Z. Y. (2016). Designing a five star hotel with the approach of sustainable architecture in Bandar Abbas. Turkish Online Journal of Design, Art and Communication, 6(JLYSPCL), 891-897.Available at: https://doi.org/10.7456/1060jse/058.

Aznar, J. P., Sayeras, J. M., Galiana, J., \& Rocafort, A. (2016). Sustainability commitment, new competitors' presence, and hotel performance: The hotel industry in Barcelona. Sustainability, 8(8), 1-13.Available at: https://doi.org/10.3390/su8080755.

BA (Hons) Hotel and Hospitality Management. (2020). Why sustainability is key for the future of the hospitality industry. Retrieved from: https://www.southwales.ac.uk/courses/ba-hons-hotel-and-hospitality-management/2484/whysustainability-is-key-for-the-future-of-the-hospitality-industry/.

Barber, N. A., \& Deale, C. (2013). Tapping mindfulness to shape hotel guests' sustainable behavior. Cornell Hospitality Quarterly, 55(1), 100-114.Available at: https://doi.org/10.1177/1938965513496315. 
Brundtland, G. H. (1987). Our common future: Report of the 1987 world commission on environment and development. Oslo: United Nations.

Burton, S. (2019). Handbook of sustainable refurbishment. Housing, S.l: Routledge.

Eskerod, P., Hollensen, S., Morales-Contreras, M. F., \& Arteaga-Ortiz, J. (2019). Drivers for pursuing sustainability through IoT technology within high-end hotels—an exploratory study. Sustainability, 11(19), 5372.Available at: https://doi.org/10.3390/su11195372.

Fournier, J.-M., \& Fall, F. (2017). Limits to government debt sustainability in OECD countries. Economic Modelling, 66, 30-41.

Fraj, E., Matute, J., \& Melero, I. (2015). Environmental strategies and organizational competitiveness in the hotel industry: The role of learning and innovation as determinants of environmental success. Tourism Management, 46, 30-42.Available at: https://doi.org/10.1016/j.tourman.2014.05.009.

Gohardani, N., \& Björk, F. (2012). Sustainable refurbishment in building technology. Smart and Sustainable Built Environment, 1(3), 241-252.Available at: https://doi.org/10.1108/20466091211287128.

Goodland, R. (1995). The concept of environmental sustainability. Annual Review of Ecology and Systematics, 26(1), 1-24.

Grant, M. (2020). Understanding sustainability. Retrieved from https://www.investopedia.com/terms/s/sustainability.asp.

Guix, M., Bonilla-Priego, M. J., \& Font, X. (2018). The process of sustainability reporting in international hotel groups: An analysis of stakeholder inclusiveness, materiality and responsiveness. Journal of Sustainable Tourism, 26(7), 10631084.Available at: https://doi.org/10.1080/09669582.2017.1410164.

Han, H., Hsu, L.-T. J., \& Lee, J.-S. (2009). Empirical investigation of the roles of attitudes toward green behaviors, overall image, gender, and age in hotel customers' eco-friendly decision-making process. International Journal of Hospitality Management, 28(4), 519-528.Available at: https://doi.org/10.1016/j.ijhm.2009.02.004.

Harmon, W. (2017). The future of sustainability in the hospitality industry. Retrieved from https://www.bluecart.com/blog/the-future-of-sustainability-in-the-hospitality-industry.

Kasemsap, K. (2018). Encouraging corporate social responsibility and sustainable tourism development in global tourism. In Operations and Service Management: Concepts, Methodologies, Tools, and Applications (pp. 1028-1056). Thailand: IGI Global.

Kim, Y. H., Barber, N., \& Kim, D.-K. (2019). Sustainability research in the hotel industry: Past, present, and future. Journal of Hospitality Marketing \& Management, 28(5), 576-620.Available at: https://doi.org/10.1080/19368623.2019.1533907.

Lengyel, A. (2015). Mindfulness and sustainability: Utilizing the tourism context. Journal of Sustainable Development, 8(9), 3551.Available at: https://doi.org/10.5539/jsd.v8n9p35.

Lim, W. M. (2017). Inside the sustainable consumption theoretical toolbox: Critical concepts for sustainability, consumption, and marketing. Journal of Business Research, 78, 69-80.Available at: https://doi.org/10.1016/j.jbusres.2017.05.001.

Millar, M., \& Baloglu, S. (2011). Hotel guests' preferences for green guest room attributes. Cornell Hospitality Quarterly, 52(3), 302-311.Available at: https://doi.org/10.1177/1938965511409031.

Nastu, J. (2017). Sustainability in the hotel industry driven by demand. Retrieved from https://www.environmentalleader.com/2017/10/174680/.

Peng, T., Kellens, K., Tang, R., Chen, C., \& Chen, G. (2018). Sustainability of additive manufacturing: An overview on its energy demand and environmental impact. Additive Manufacturing, 21, 694-704.Available at: https://doi.org/10.1016/j.addma.2018.04.022.

Petri, L., \& Mikuli, D. (2012). Protected areas and tourism development on Croatian islands: Coexistence or divergence? WIT Transactions on Ecology and the Environment, 166, 29-40.

Pickering, C., Grignon, J., Steven, R., Guitart, D., \& Byrne, J. (2015). Publishing not perishing: How research students transition from novice to knowledgeable using systematic quantitative literature reviews. Studies in Higher Education, 4O(10), 1756-1769.

Punitha, S., \& Rasdi, R. M. (2013). Corporate social responsibility: Adoption of green marketing by hotel industry. Asian Social Science, 9(17), 79.Available at: https://doi.org/10.5539/ass.v9n17p79. 
Rahman, I., Reynolds, D., \& Svaren, S. (2012). How "green" are North American hotels? An exploration of low-cost adoption practices. International Journal of Hospitality Management, 31(3), 720-727.Available at: https://doi.org/10.1016/j.ijhm.2011.09.008.

Rosa, F. S. D., \& Silva, L. C. (2017). Environmental sustainability in hotels, theoretical and methodological contribution. Brazilian Journal of Tourism Research, 11(1), 39-60.

Ryu, H. (2014). Sustainable building refurbishment. Master's Thesis: Aalto University, Espoo, Finland.

Sloan, P., Legrand, W., \& Chen, J. (2017). Sustainability in the hospitality industry principles of sustainable operations (3rd ed.). London: Routledge.

Stipanuk, D. M. (2002). Hospitality facilities management and design. Lansing: Educational Institute of the American Hotel \& Lodging Association.

Tanveer, N. (2019). Top 7: World's most sustainable hotels. Retrieved from https://www.abouttimemagazine.co.uk/travel/top7-worlds-most-sustainable-hotels/.

Tooman, H., Sloan, P., Legrand, W., \& Fendt, J. (2008). Case studies of best practices in sustainability in German and Estonian. Paper presented at the Conference Proceedings of the EuroChrie.

Tripathi, A., \& Singh, M. P. (2016). Determinants of sustainable/green consumption: a review. International Journal of Environmental Technology and Management, 19(3-4), 316-358.Available at: https://doi.org/10.1504/ijetm.2016.082258.

Verma, V. K., \& Chandra, B. (2018). Sustainability and customers' hotel choice behaviour: A choice-based conjoint analysis approach. Environment, Development and Sustainability, 2O(3), 1347-1363.Available at: https://doi.org/10.1007/s 10668017-9944-6.

Walsh, P. R., \& Dodds, R. (2017). Measuring the choice of environmental sustainability strategies in creating a competitive advantage. Business Strategy and the Environment, 26(5), 672-687.Available at: https://doi.org/10.1002/bse.1949.

Webster, A., \& Courtnell, J. (2019). Economic sustainability for success: What it is and how to implement it: Process street: Checklist, workflow and SOP software. Retrieved from https://www.process.st/economic-sustainability/.

Yang, E. C. L., Khoo-Lattimore, C., \& Arcodia, C. (2017). A systematic literature review of risk and gender research in tourism. Tourism Management, 58, 89-100.Available at: https://doi.org/10.1016/j.tourman.2016.10.011.

Zhang, J. J., Joglekar, N. R., \& Verma, R. (2012). Exploring resource efficiency benchmarks for environmental sustainability in hotels. Cornell Hospitality Quarterly, 53(3), 229-241.Available at: https://doi.org/10.1177/1938965512441165.

Zhang, L., Wu, J., Liu, H., \& Zhang, X. (2017). The value of going green in the hotel industry: Evidence from Beijing. Real Estate Economics, 48(1), 174-199.Available at: https://doi.org/10.1111/1540-6229.12225.

Zolfani, S. H., Pourhossein, M., Yazdani, M., \& Zavadskas, E. K. (2018). Evaluating construction projects of hotels based on environmental sustainability with MCDM framework. Alexandria Engineering Journal, 57(1), 357-365.Available at: https://doi.org/10.1016/j.aej.2016.11.002.

Views and opinions expressed in this article are the views and opinions of the author(s), Journal of Tourism Management Research shall not be responsible or answerable for any loss, damage or liability etc. caused in relation to/arising out of the use of the content. 